\title{
Anti-inflammatory effect of Malus domestica cv. Green ball apple peel extract on Raw 264.7 macrophages
}

\author{
Eun-Ho Lee ${ }^{1} \cdot$ Hye-Jin Park ${ }^{1}$ Byung-Oh Kim ${ }^{1} \cdot$ Hyong-Woo Choi ${ }^{2}$. \\ Kyeung-Il Park ${ }^{3} \cdot$ In-Kyu Kang ${ }^{4} \cdot$ Young-Je Cho ${ }^{1}$
}

Received: 5 February 2020 / Accepted: 17 March 2020 / Published Online: 30 June 2020

(C) The Korean Society for Applied Biological Chemistry 2020

\begin{abstract}
We examined the anti-inflammatory effect of the peel extract of the newly bred Korean apple (Malus domestica Borkh.) cultivar Green ball. To test its possible use as anti-inflammatory functional material, Raw 264.7 macrophages were treated with pro-inflammatory lipopolysaccharide (LPS) in the presence or absence of Green ball apple peel ethanol extract (GBE). Notably, up to $500 \mu \mathrm{g} / \mathrm{mL}$ of GBE did not result in any signs of inhibition on cellular metabolic activity or cytotoxicity in Raw 264.7 macrophages. Supplementation with GBE to LPS-treated Raw 264.7 macrophage significantly suppressed various pro-inflammatory responses in a dose-dependent manner, including i) nitric oxide (NO) production, ii) accumulation of inducible NO synthase and cyclooxygenase-2, iii) phosphorylation of nuclear factor-kappa $\mathrm{B}$ $(\mathrm{NF}-\kappa \mathrm{B})$ subunit $\mathrm{p} 65$, and iv) expression of pro-inflammatory biomarker genes, including tumor necrosis factor alpha, interleukin 1 beta, interleukin 6 , monocyte chemoattractant protein-1, and prostaglandin E synthase 2 .
\end{abstract}

Keywords Anti-inflammation · Apple peel · Biomarker genes · Green ball $\cdot$ Lipopolysaccharide

Young-Je Cho $(\bowtie)$

E-mail:yjcho@knu.ac.kr

${ }^{1}$ School of Food science \& Biotechnology, Kyungpook National University, 80 Daehakro, Bukgu, Daegu 41566, Republic of Korea

${ }^{2}$ Department of Plant Medicals, Andong National University, 1375 Kyeongdongro, Andong 36729, Republic of Korea

${ }^{3}$ Department of Horticulture and Life Science, Yeungnam University, 280 Daehakro, Gyeongsan 38541, Republic of Korea

${ }^{4}$ Department of Horticultural Science, Kyungpook National University, 80 Daehakro, Bukgu, Daegu 41566, Republic of Korea

This is an Open Access article distributed under the terms of the Creative Commons Attribution Non-Commercial License (http://creativecommons. org/licenses/by-nc/3.0/) which permits unrestricted non-commercial use, distribution, and reproduction in any medium, provided the original work is properly cited.

\section{Introduction}

Apple (Malus domestica Borkh.) fruits are nutritious and beneficial for human health, as they contains various physiologically active substances, such as vitamins, minerals, organic acids, sugars, and anti-oxidative polyphenolic compounds [1,2]. Anti-oxidative polyphenolic compounds are reported to effectively reduce the risk of human diseases like skin aging, obesity, inflammation, arteriosclerosis, diabetes, high blood pressure, and certain cancers [3]. The majority of previous studies on apple were conducted on the whole apple or tree, which basic part of the user of most and contains flavonoids, anthocyanin, and carotene as well as phenolic compounds (viz., procyanidin, chlorogenic acid, caffeic acid, quercetin, rutin) [2,3]. In particular, quercetin flavanol is an active ingredient in many plant medicines and is used in a variety of products ('Condition', CJ HealthCare, Seoul, Korea; 'Quercetin with bromelain', iHerb, Moreno valley, CA, USA) [1,4]. In addition, polyphenols, which are highly contained in apple peels, have preventive effects on diseases like endogenous and/or exogenous aging, skin aging, inflammation, and cancer caused by oxidative stress [4].

Human cells are continuously exposed to various oxidative stresses, and insufficient levels of antioxidants lead to accumulation of reactive oxygen species (ROS), causing cell damage and inflammation [4-6]. The inflammation process is mediated by immune-related cells, such as macrophages and $T$ cells [7]. The inflammatory response is primarily caused by microbial infection, resulting in the local release of pro-inflammatory chemical mediators, such as histamine, bradykinin, arachidonic acid, prostaglandin (PG), leukotriene, cytokine, chemokine, nitric oxide (NO), and serotonin by immune-related cells. These proinflammatory chemical mediators increase vascular permeability and vasodilation and also induce fever, redness, pain, and swelling $[8,9]$. Inducible nitric oxide synthase (iNOS) and cyclooxygenase2 (COX-2) are well known inflammation-related enzymes which produce pro-inflammatory $\mathrm{NO}$ and $\mathrm{PG}$, respectively $[10,11]$. 
Expression of COX-2, in particular, leads to expression of inflammatory biomarker genes for compounds like tumor necrosis factor alpha (TNF- $\alpha$ ), interleukin 1 beta (IL-1 $)$, interleukin 6 (IL$6)$, monocyte chemoattractant protein-1 (MCP-1), interferon- $\gamma$ (IFN- $\gamma$ ), and prostaglandin E synthase 2 (PTGES2) [10,11]. Under inflammatory conditions, ROS induces structural and functional changes in DNA and protein molecules via oxidation and enhances the cellular levels of malondialdehyde produced by lipid peroxidation [12]. Ultimately, oxidative stress can cause reversible and/or irreversible damage to cells, lowers cell functioning, and causes chronic diseases like arteriosclerosis and cancer.

Thus, in this study, we aimed to evaluate the anti-inflammatory function of apple peel extract of the newly bred Korean apple (Malus domestica Borkh.) cultivar Green ball by measuring alteration of lipopolysaccharide (LPS)-induced inflammatory responses in Raw 264.7 macrophage.

\section{Materials and Methods}

\section{Samples and sample preparation}

In this study, the apple cultivar 'Green ball' was used. This cultivar was developed by Apple Research Institute (National Institute of Horticultural \& Herbal Science, Gunwi 39000, Korea) in 2008 by crossing the 'Golden Delicious' and 'Fuji' varieties. The apple fruit samples were harvested from trees (/M.9, 8 years old) grown at Apple Research Institute, washed with distilled water, and apple peels were collected for further experiments. Collected apple peels were lyophilized in a freeze dryer (FD8518; ilShin BioBase, Yangju, Korea). After lyophilization, the samples were passed through a 40 mesh screen and stored at $-80{ }^{\circ} \mathrm{C}$ until use.

\section{Preparation of total phenolic extracts from Green ball apple peels}

Green ball apple peel ethanol extract (GBE) were prepared as previously reported $[1,13]$. Briefly, $1 \mathrm{~g}$ of fruit powder was mixed with $100 \mathrm{~mL}$ of $10-100 \%$ ethanol and stored at $4{ }^{\circ} \mathrm{C}$ for $24 \mathrm{~h}$ with shaking. Ethanol extracts were filtered through Whatman No. 1 filter paper (Whatman Inc., Piscataway, NJ, USA), lyophilized in a freeze dryer (FD8518; ilShin BioBase, Yangju, Korea), and stored at $-20{ }^{\circ} \mathrm{C}$ until use. GBE were tested at concentrations ranging from 100 to $500 \mu \mathrm{g} / \mathrm{mL}$.

\section{Raw 264.7 macrophage cell culture}

The Raw 264.7 macrophages line was purchased from Korean Cell Line Research Foundation. Cells were cultured in DMEM high glucose medium (HyClone Laboratories, Inc., Logan, UT, USA) supplemented with 10\% FBS (HyClone Laboratories, Inc.) and $1 \%$ penicillin-streptomycin (HyClone Laboratories, Inc.). All incubations were performed at $37{ }^{\circ} \mathrm{C}$ with $95 \%$ humidity and an atmosphere of $5 \% \mathrm{CO}_{2}$ (311, Thermo Fisher Scientific, Rockford,
IL, USA). Cells were passaged after reaching 80-90\% confluence. Experiments were conducted using cells that did not exceed 20 passages.

\section{MTT assay}

The 3-(4,5-dimethylthiazol-2-yl)-2,5-diphenyltetrazolium bromide (MTT) assay was performed to test the cytotoxicity of GBE on Raw 264.7 macrophages, as previously reported [14]. Raw 264.7 macrophages were seeded in 48-well tissue culture plates at $5 \times 10^{3}$ cells $/ \mathrm{mL}$ in complete medium (DMEM medium supplemented with $10 \%$ heat-inactivated FBS). Plates were incubated for $24 \mathrm{~h}$ in a $\mathrm{CO}_{2}$ incubator at $37{ }^{\circ} \mathrm{C}$. The following day, cells were treated with different concentrations of GBE $(100-500 \mu \mathrm{g} / \mathrm{mL})$ and allowed to grow for $18 \mathrm{~h}$. After incubation, $50 \mu \mathrm{L}$ of $5 \mathrm{mg} / \mathrm{mL}$ MTT (Sigma-Aldrich Co., St. Louis, MO, USA) was added. The plates were incubated for $4 \mathrm{~h}$, incubation media was discarded, and $500 \mu \mathrm{L}$ of dimethyl sulfoxide was added to solubilize the formazan. After $10 \mathrm{~min}$ of shaking at room temperature, the $\mathrm{OD}_{590 \mathrm{~nm}}$ was measured using an ELISA reader (SPECTRO star Nano, BMG LABTECH, Ortenberg, Germany). Cell viability (\%) was calculated as follows: cell viability $(\%)=\left[\left(\mathrm{OD}_{590}\right.\right.$ of $\mathrm{GBE}$ treated cell $) /\left(\mathrm{OD}_{590}\right.$ of $\mathrm{GBE}$ untreated cell $\left.)\right] \times 100$.

\section{Measurement of NO production}

NO production was measured as nitrite $\left(\mathrm{NO}_{2}^{-}\right)$and nitrate $\left(\mathrm{NO}_{3}{ }^{-}\right)$ using the Griess reagent system kit (Promega, Madison, WI, USA). Raw 264.7 macrophages were seeded in 96-well tissue culture plates at $5 \times 10^{4}$ cells $/ \mathrm{mL}$ in complete medium, and plates were incubated for $24 \mathrm{~h}$ in a $\mathrm{CO}_{2}$ incubator at $37^{\circ} \mathrm{C}$. Cells were treated the following day with indicated concentrations of LPS $(1 \mu \mathrm{g} / \mathrm{mL})$ and GBE $(100-500 \mu \mathrm{g} / \mathrm{mL})$ and allowed to grow for $18 \mathrm{~h}$. Griess reagent $(1 \%$ sulfanilamide $+0.1 \%$ naphthylendiamine dihydrochloride) was mixed with the cell culture supernatant at a 1:1 ratio, and the NO level was measured at $\mathrm{OD}_{540 \mathrm{~nm}}$ using an ELISA reader (SPECTRO star Nano, BMG LABTECH). The concentration of $\mathrm{NO}$ in the cell culture supernatant was calculated using a sodium nitrite $\left(\mathrm{NaNO}_{2}\right)$ standard curve. The inhibition rate was calculated as follows: Inhibition rate $(\%)=[1-($ Absorbance of sample/Absorbance of control) $] \times 100$.

\section{Immunoblotting}

Measurements of iNOS and COX-2 protein expression levels were conducted using Raw 264.7 macrophages seeded in 6-well tissue culture plates at $5 \times 10^{5}$ cells $/ \mathrm{mL}$. After incubating for $24 \mathrm{~h}$ in a $\mathrm{CO}_{2}$ incubator at $37^{\circ} \mathrm{C}, 1 \mu \mathrm{g} / \mathrm{mL}$ LPS and/or indicated concentrations of GBE $(100-500 \mu \mathrm{g} / \mathrm{mL})$ were added, and the plates were incubated for $18 \mathrm{~h}$ and washed with PBS. Seventy microliters of a mixture of M-PER Mammalian Protein Extraction Reagent (Thermo Fisher Scientific) with $1 \times$ protease inhibitor (Thermo Fisher Scientific) was added to each well and cells were lysed at $4{ }^{\circ} \mathrm{C}$, followed by centrifugation at $16,000 \times \mathrm{g}$ for $20 \mathrm{~min}$ at $4{ }^{\circ} \mathrm{C}$ (Gyrozen, Seoul, Korea) to remove insoluble debris. NF- 
$\kappa \mathrm{B}$ protein phosphorylation levels were measured using Raw 264.7 macrophages seeded in $100 \times 20 \mathrm{~mm}$ tissue culture plates at $2 \times 10^{6}$ cells $/ \mathrm{mL}$ and incubated for $24 \mathrm{~h}$ in a $\mathrm{CO}_{2}$ incubator at $37^{\circ} \mathrm{C}$. After incubation, $1 \mu \mathrm{g} / \mathrm{mL}$ LPS and/or indicated concentrations of GBE $(200-500 \mu \mathrm{g} / \mathrm{mL})$ were added, and the plates were incubated for $0.5 \mathrm{~h}$ and washed with ice-cold PBS. Cytoplasmic and nuclear proteins were extracted by using nuclear and cytoplasmic extraction reagents (Thermo Fisher Scientific) with $1 \times$ protease and $1 \times$ phosphatase inhibitors (Thermo Fisher Scientific). The protein concentrations were measured using a BCA Protein Assay Kit (Thermo Fisher Scientific). Forty micrograms of protein per sample was separated using $10 \%$ SDS-PAGE and transferred to a PVDF membrane for immunoblotting (IB) using anti-iNOS, anti-

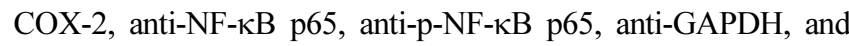
anti- $\beta$-actin antibodies (Santa Cruz Biotechnology, Dallas, TX, USA). For quantification of relative iNOS, COX-2, NF- $\kappa \mathrm{B}$ p65, and $\mathrm{p}-\mathrm{NF}-\mathrm{\kappa} \mathrm{B}$ p 65 , densitometry was performed using an imaging system (C300, Azure Biosystems Inc., Dublin, CA, USA).

Expression analysis of inflammatory biomarker genes by using real-time PCR

Raw 264.7 macrophages were seeded in $100 \times 20 \mathrm{~mm}$ tissue culture plates at $5 \times 10^{6}$ cells $/ \mathrm{mL}$. After a $24 \mathrm{~h}$ incubation in a $\mathrm{CO}_{2}$ incubator at $37^{\circ} \mathrm{C}, 1 \mu \mathrm{g} / \mathrm{mL}$ LPS and/or indicated concentrations of $\operatorname{GBE}(100,300$, and $500 \mu \mathrm{g} / \mathrm{mL})$ were added, and the plates were incubated for $18 \mathrm{~h}$ and washed with ice-cold PBS. Total
RNA was extracted by using a GeneAll ${ }^{\circledR}$ Ribospin RNA extraction kit (GeneAll Biotechnology Co., Seoul, Korea) and used for cDNA synthesis with a qPCRBIO cDNA synthesis kit (PCR Biosystems, London, UK). One microliter of 1:1 diluted cDNA was used for real-time PCR with $5 \mu \mathrm{L}$ Real-time PCR master mix (GeneAll Biotechnology Co.) and the PCRmax Eco 48 real-time PCR system (PCRmax, Staffordshire, UK). PCR conditions and primer sequences are listed (Tables 1, 2).

\section{Statistical analysis}

All experiments were repeated at least three times. SPSS 23 for Windows was used for analysis (Statistical Package for Social Science, SPSS Inc., Chicago, IL, USA). One-way analysis of variance (ANOVA) and Duncan's multiple range test were used to determine the significance of differences between the samples at $p<0.05$ or $p<0.01$.

\section{Results}

\section{GBE is not cytotoxic to Raw 264.7 macrophages}

To confirm the cytotoxic effect of GBE, cell viability of Raw 264.7 macrophages was measured using an MTT assay (Fig. 1). Treatment with different concentrations of GBE did not alter cellular metabolic activities. No significant alterations in the metabolic activity were observed in cells treated with the highest

Table 1 The sequences of primers used for real-time PCR

\begin{tabular}{|c|c|c|c|c|}
\hline Gene name & Accession & primer & Sequence (5'-3') & Amplicon (b.p.) \\
\hline \multirow{2}{*}{ TNF- $\alpha$} & \multirow{2}{*}{ NM_001278601.1 } & Forward & 5'-TCTACTGAACTTCGGGGTGA-3' & \multirow{2}{*}{87} \\
\hline & & Reverse & 5'-AGGGTCTGGGCCATAGAACT-3' & \\
\hline \multirow{2}{*}{ IL-1 $\beta$} & \multirow{2}{*}{ NM_008361.4 } & Forward & 5'-CAACCAACAAGTGATATTCTCCATG-3' & \multirow{2}{*}{152} \\
\hline & & Reverse & 5'-GATCCACACTCTCCAGCTGCA-3' & \\
\hline \multirow{2}{*}{ IL-6 } & \multirow{2}{*}{ NM_031168.2 } & Forward & 5'-TAGTCCTTCCTACCCCAATTTCC-3' & \multirow{2}{*}{76} \\
\hline & & Reverse & 5'-TTGGTCCTTAGCCACTCCTTC-3' & \\
\hline \multirow{2}{*}{ MCP-1 } & \multirow{2}{*}{ NM_011333.3 } & Forward & 5'-TTCCTCCACCACCATGCAG-3' & \multirow{2}{*}{64} \\
\hline & & Reverse & 5'-CCAGCCGGCAACTGTGA-3' & \\
\hline \multirow{2}{*}{ PTGES2 } & \multirow{2}{*}{ NM_133783.2 } & Forward & 5'-CCGTGAGAAGGACTGAGATC-3' & \multirow{2}{*}{162} \\
\hline & & Reverse & 5'-AAGTGATGACCTCTTCCAGG-3' & \\
\hline \multirow{2}{*}{$\beta$-actin } & \multirow{2}{*}{ NM_007393.4 } & Forward & 5'-CGTGCGTGACATCAAAGAGAA-3' & \multirow{2}{*}{137} \\
\hline & & Reverse & 5'-GCTCGTTGCCAATAGTGATGA-3' & \\
\hline
\end{tabular}

Table 2 Real-time PCR conditions

\begin{tabular}{|c|c|}
\hline Factors & Real-time PCR condition \\
\hline TNF- $\alpha$ & $95^{\circ} \mathrm{C}$ for $5 \mathrm{~min}$, followed by 40 cycles of $95^{\circ} \mathrm{C}$ for $10 \mathrm{~s}, 60^{\circ} \mathrm{C}$ for $20 \mathrm{~s}$, followed by $95,55,95^{\circ} \mathrm{C}$ for $15 \mathrm{~s}$, each \\
\hline IL-1 $\beta$ & $95^{\circ} \mathrm{C}$ for $5 \mathrm{~min}$, followed by 40 cycles of $95^{\circ} \mathrm{C}$ for $10 \mathrm{~s}, 60^{\circ} \mathrm{C}$ for $20 \mathrm{~s}$, followed by $95,55,95^{\circ} \mathrm{C}$ for $15 \mathrm{~s}$, each \\
\hline IL-6 & $95^{\circ} \mathrm{C}$ for $5 \mathrm{~min}$, followed by 40 cycles of $95^{\circ} \mathrm{C}$ for $10 \mathrm{~s}, 60^{\circ} \mathrm{C}$ for $20 \mathrm{~s}, 72^{\circ} \mathrm{C}$ for $15 \mathrm{~s}$, followed by $95,55,95{ }^{\circ} \mathrm{C}$ for $15 \mathrm{~s}$, each \\
\hline MCP-1 & $95^{\circ} \mathrm{C}$ for $5 \mathrm{~min}$, followed by 40 cycles of $95^{\circ} \mathrm{C}$ for $10 \mathrm{~s}, 60^{\circ} \mathrm{C}$ for $20 \mathrm{~s}$, followed by $95,55,95^{\circ} \mathrm{C}$ for $15 \mathrm{~s}$, each \\
\hline PTGES2 & $95^{\circ} \mathrm{C}$ for $5 \mathrm{~min}$, followed by 40 cycles of $95^{\circ} \mathrm{C}$ for $10 \mathrm{~s}, 60^{\circ} \mathrm{C}$ for $20 \mathrm{~s}$, followed by $95,55,95^{\circ} \mathrm{C}$ for $15 \mathrm{~s}$, each \\
\hline$\beta$-actin & $\begin{array}{l}95^{\circ} \mathrm{C} \text { for } 5 \mathrm{~min} \text {, followed by } 40 \text { cycles of } 95^{\circ} \mathrm{C} \text { for } 10 \mathrm{~s}, 60^{\circ} \mathrm{C} \text { for } 20 \mathrm{~s} \text { or } 95^{\circ} \mathrm{C} \text { for } 10 \mathrm{~s}, 60^{\circ} \mathrm{C} \text { for } 20 \mathrm{~s}, 72^{\circ} \mathrm{C} \text { for } 15 \mathrm{~s} \text {, followed } \\
\text { by } 95,55,95^{\circ} \mathrm{C} \text { for } 15 \mathrm{~s} \text {, each }\end{array}$ \\
\hline
\end{tabular}




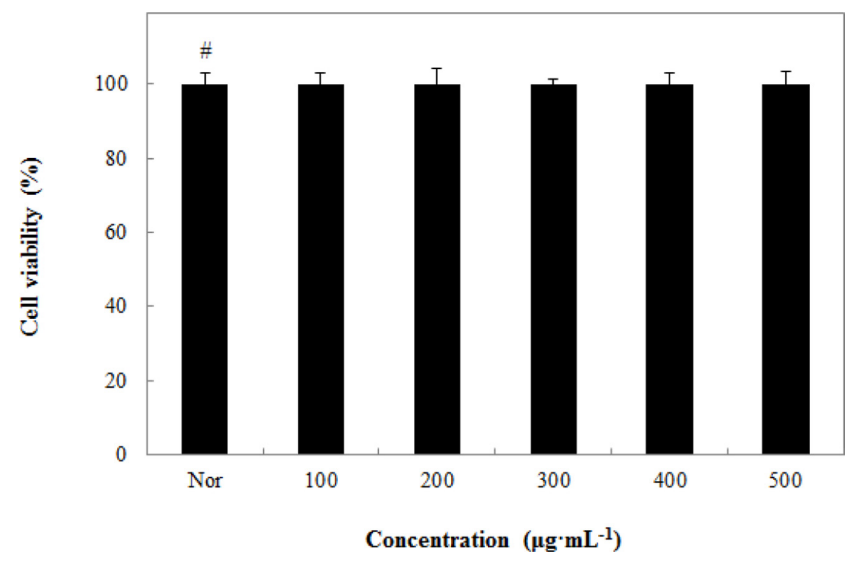

Fig. 1 MTT assay of Raw 264.7 macrophages treated with GBE. Raw 264.7 macrophages were stimulated with LPS $(1 \mu \mathrm{g} / \mathrm{mL})$ in the presence of different concentrations of GBE $(100-500 \mu \mathrm{g} / \mathrm{mL})$ for $18 \mathrm{~h}$. Data presented as means \pm SD of three independent experiments $(n=3)$. No significant differences were observed between GBE-untreated and GBEtreated groups $(p<0.01)$. Nor: Normal GBE-untreated

concentration of GBE, suggesting GBE is not cytotoxic. Therefore, $500 \mu \mathrm{g} / \mathrm{mL}$ was used in the following experiments.

\section{GBE suppresses NO production in LPS-stimulated Raw 264.7} macrophages

NO generation was measured in Raw 264.7 macrophages stimulated with $1 \mu \mathrm{g} / \mathrm{mL}$ LPS in the presence of different concentrations of GBE (Fig. 2). NO production was significantly reduced to $91.02,87.84,80.29,74.14$, and $74.73 \%$ by 100,200 , 300,400 , and $500 \mu \mathrm{g} / \mathrm{mL}$ GBE, respectively, as compared to the GBE-untreated control. At the highest concentration of GBE (500 $\mu \mathrm{g} / \mathrm{mL}$ ), approximately a $25.2 \%$ reduction in LPS-induced NO production was observed. This suggests that GBE can significantly attenuate the inflammatory response in Raw 264.7 macrophages. NO is produced during inflammatory responses and functions as an antibacterial, anticancer, and vasodilation agent in the immune system [15]. However, excessive production of NO can damage cells or tissues and induce mutations in DNA. Thus, NO is often used as a biomarker for inflammatory responses [15].

GBE suppresses accumulation of iNOS and COX-2, as well as activation of $\mathrm{NF}-\kappa \mathrm{B}$

To confirm the phosphorylation status of nuclear factor-kappa B $(\mathrm{NF}-\mathrm{\kappa B})$ involved in iNOS and COX-2 protein expression, different concentrations of GBE were used to treat LPS-stimulated Raw 264. 7 macrophages (Fig. 3). Consistent with GBE's suppressive effect on LPS-induced NO production in Raw 264.7 macrophages, iNOS expression was significantly reduced by $99.97,72.74$, $54.96,41.51$, and $31.73 \%$ at $100,200,300,400$, and $500 \mu \mathrm{g} / \mathrm{mL}$, respectively (Fig. 3A). The highest concentration of GBE $(500 \mu \mathrm{g} /$ $\mathrm{mL}$ ) reduced iNOS expression up to $68.27 \%$. GBE treatment also significantly reduced LPS-induced COX-2 expression in a dose-

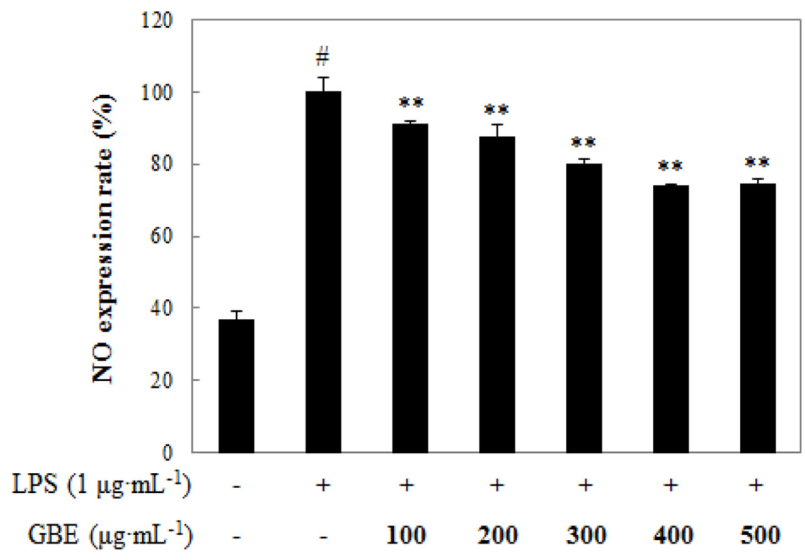

Fig. 2 Effect of GBE on NO production in LPS-stimulated Raw 264.7 macrophages. Raw 264.7 macrophages were treated with LPS $(1 \mu \mathrm{g} / \mathrm{mL})$ in the presence of various concentrations GBE $(100-500 \mu \mathrm{g} / \mathrm{mL})$ for $18 \mathrm{~h}$. LPS- and GBE-untreated cells served as negative control. LPS-treated cells served as a positive control. The values are mean $\pm \mathrm{SD}$ of three independent experiments. ${ }^{\#} p<0.05$ compared with negative control group, $* p<0.05, * * p<0.01$ compared with positive control group

dependent manner (Fig. 3B). Expression of COX-2 was significantly reduced to $93.69,79.20,57.82,43.26$, and $18.44 \%$ by $100,200,300,400$, and $500 \mu \mathrm{g} / \mathrm{mL}$ GBE, respectively. Although the endogenous level of NF- $\kappa B$ subunit p65 was not significantly altered by LPS treatment, the level of phosphorylation (or activation) was significantly increased (Fig. 4). However, LPSinduced p65 phosphorylation was significantly reduced to 61.73 , $63.02,54.70$ and $43.41 \%$ by $200,300,400$ and $500 \mu \mathrm{g} / \mathrm{mL}$ GBE treatment, respectively. In summary, LPS-induced expression of pro-inflammatory iNOS and COX-2 and phosphorylation of NF$\kappa \mathrm{B}$ subunit $\mathrm{p} 65$ were significantly suppressed by GBE in a dosedependent manner. This suggests that GBE-mediated suppression of NF- $\mathrm{KB}$ activation might lead to suppression of downstream iNOS and COX-2 production. Taken together, our results suggest that GBE can be used as a potential anti-inflammatory functional material.

\section{GBE downregulates expression of inflammatory biomarker genes}

Expression of pro-inflammatory biomarker genes TNF- $\alpha$, IL- $1 \beta$, IL-6, MCP-1, and PTGES2 were examine in LPS-stimulated Raw 264.7 macrophages treated with different concentrations of GBE (Figs. 5A-E). Expression of TNF- $\alpha$ was significantly reduced to 88,42 and $6 \%$ by treatment with 100,300 , and $500 \mu \mathrm{g} / \mathrm{mL} \mathrm{GBE}$, respectively. Notably, $500 \mu \mathrm{g} / \mathrm{mL}$ GBE treatment reduced LPSinduced TNF- $\alpha$ expression to levels similar to that of LPSuntreated Raw 264.7 macrophages. Similarly, expression of IL$1 \beta$, IL-6, MCP-1, and PTGES2 were also significantly inhibited by GBE treatment in a dose-dependent manner. In particular, the highest concentration of GBE $(500 \mu \mathrm{g} / \mathrm{mL})$ inhibited expression of MCP-1at a level similar to that observed in LPS-untreated cells 
(A)

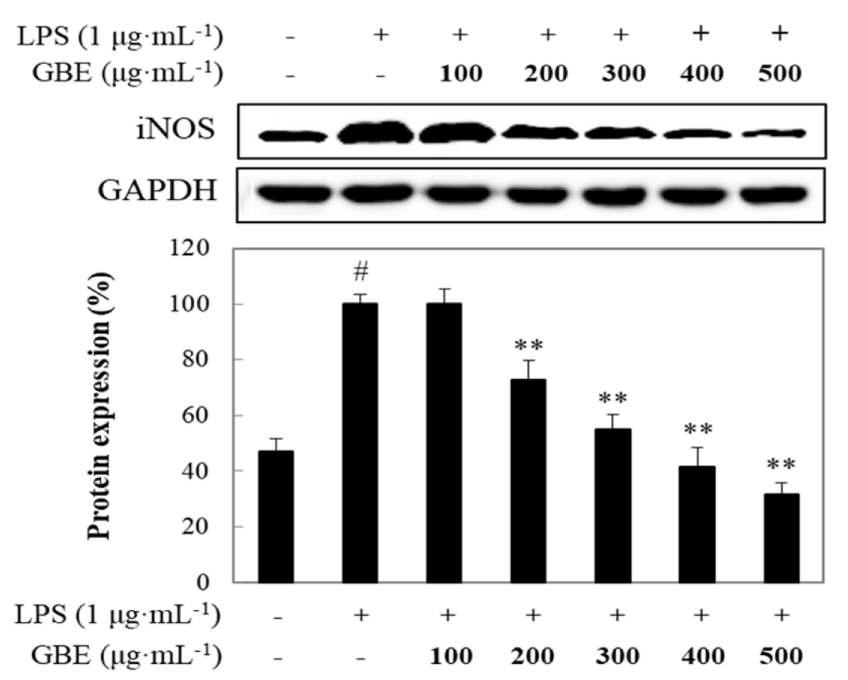

(B)

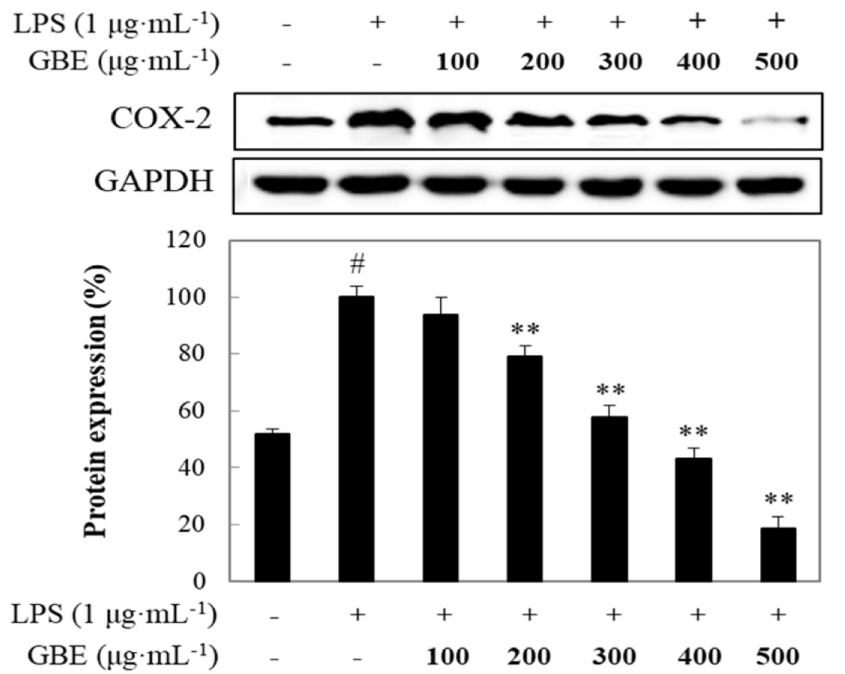

Fig. 3 Effect of GBE on the protein expression of iNOS (A) and COX-2 (B) in Raw 264.7 macrophages stimulated with LPS. Raw 264.7 macrophages were treated with LPS $(1 \mu \mathrm{g} / \mathrm{mL})$ in the presence of various concentrations of GBE $(100-500 \mu \mathrm{g} / \mathrm{mL})$ for $18 \mathrm{~h}$. LPS- and GBE-untreated cells served as a negative control. LPS-treated cells served as a positive control. The values are mean $\pm \mathrm{SD}$ of three independent experiments. ${ }^{\#} p<0.05$ compared with negative control group, ${ }^{*} p<0.05,{ }^{* *} p<0.01$ compared with positive control group

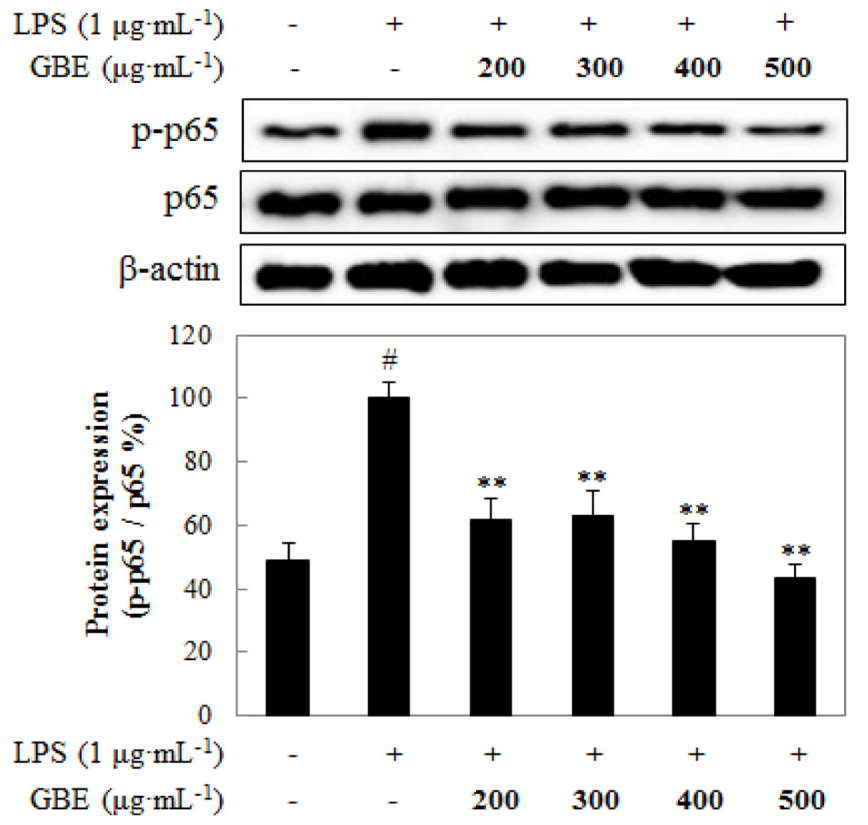

Fig. 4 Effect of GBE on the phosphorylation of NF-kB subunit p65 in Raw 264.7 macrophages stimulated with LPS. Raw 264.7 macrophages were treated with LPS $(1 \mu \mathrm{g} / \mathrm{mL})$ in the presence of different concentrations of GBE $(200-500 \mu \mathrm{g} / \mathrm{mL})$ for $30 \mathrm{~min}$. LPS- and GBEuntreated cells served as a negative control. LPS-treated cells served as a positive control. The values are mean $\pm \mathrm{SD}$ of three independent experiments. ${ }^{*} p<0.05$ compared with negative control group, ${ }^{*} p<0.05$, ${ }^{* *} p<0.01$ compared with positive control group

or, in the case of IL-1 $\beta$, IL- 6 and PTGES2, levels were even lower than those of the control.

\section{Discussion}

As a result of infection and injuries, inflammatory responses are activated, which in turn cause pain, fever, redness and swelling. LPS, also known as lipoglycans and endotoxins, are large molecules consisting of a lipid and a polysaccharide produced by Gramnegative bacteria [16]. Macrophage cells are recruited to the site of infection where they can recognize the presence of LPS via its cognate toll-like receptor (TLR)-4. iNOS produces NO from Larginine and plays a key role in regulation of inflammatory responses [15]. COX-2 catalyzes prostaglandin $\mathrm{H}_{2}\left(\mathrm{PGH}_{2}\right)$ generation from arachidonic acid (AA) [17]. Then, $\mathrm{PGH}_{2}$ is further processed to prostacyclin, prostaglandin $\mathrm{E}_{2}\left(\mathrm{PGE}_{2}\right)$, thromboxane $\mathrm{A}$, and prostaglandin $\mathrm{D}_{2}$, which have different physiological roles in humans, including in immune response [17]. Expression of both iNOS and COX-2 are induced by inflammatory stimuli, such as LPS, and their expression is known to be regulated by the phosphorylation status of NF- $\mathrm{kB}[18]$. NF- $\mathrm{\kappa B}$ is found in almost all animal cell types and is activated by various external and internal stimuli, such as biotic and abiotic stresses, cytokines, free radicals, and UV irradiation. It is also a major transcription factor of various pro-inflammatory proteins and/or cytokine genes involved in the inflammatory response [19]. Under the normal conditions, $\mathrm{NF}-\mathrm{kB}$ is sequestered in the cytoplasm by an inhibitor (IкB); however, LPS-induced phosphorylation of I $\mathrm{KB}$ by the I $\mathrm{KB}$ kinase (IKK) complex promotes IKB degradation and NF-kB phosphorylation. Phosphorylated NF- $-\mathrm{KB}$ is translocated into the nucleus where it can transcriptionally activate iNOS, COX-2, and pro-inflammatory cytokine genes $[20,21]$. This recognition activates downstream pro-inflammatory cytokine gene expression of TNF- $\alpha$, IL- 6 and 

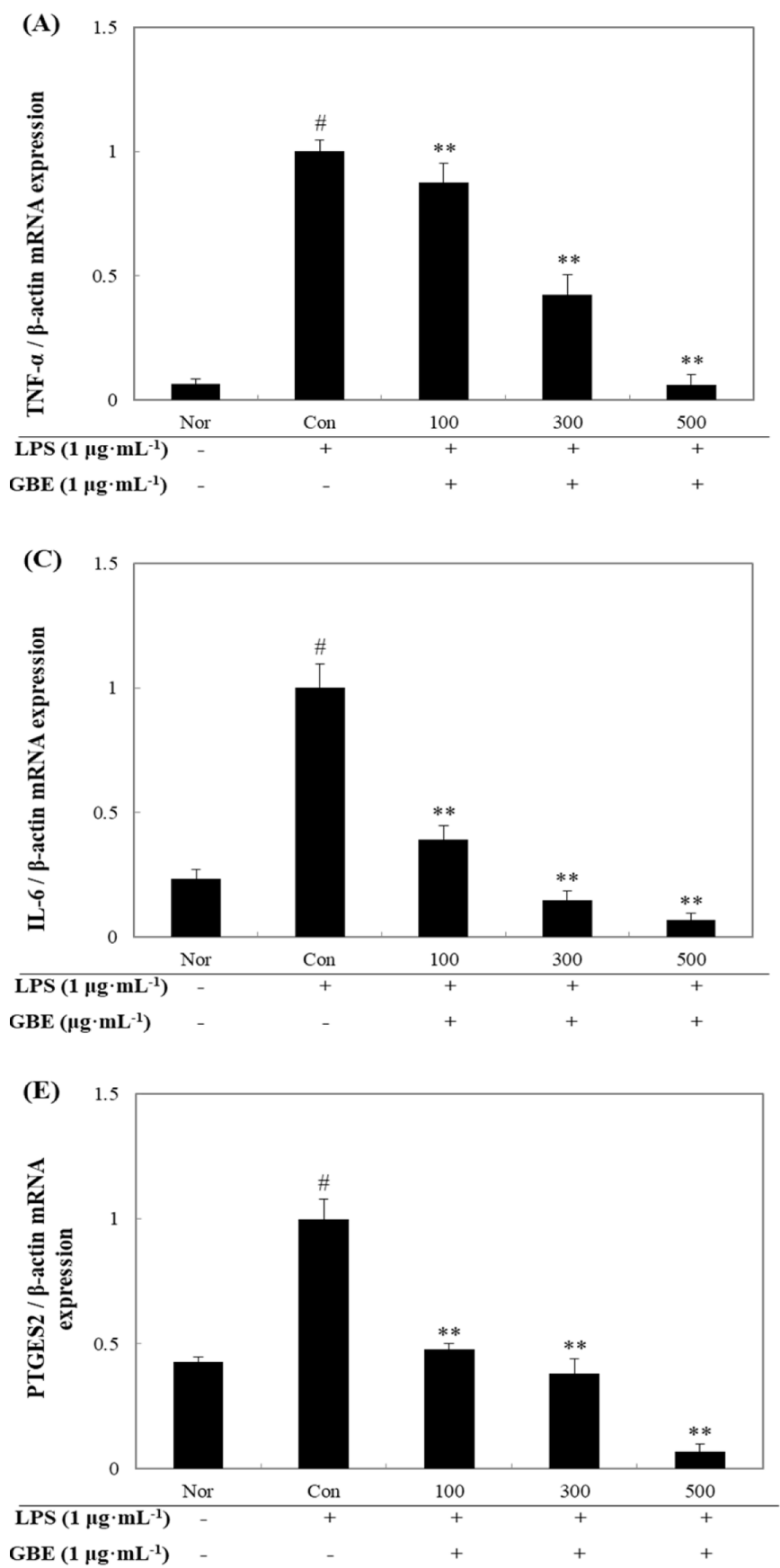

IL-1 $\beta$ [22]. During activation of inflammatory responses, cytokines promote recruitment of circulating white blood cells to the infected site. IL-1 $\beta$ and IL- 6 are known as endogenous pyrogens, whereas TNF- $\alpha$ enhances the permeability of the peripheral vascular epithelium, thus enhancing the migration of cells and watersoluble molecules from blood vessels to tissues [23]. Prostaglandin $\mathrm{H}_{2}\left(\mathrm{PGH}_{2}\right)$, the first intermediate of all prostaglandins (PGs), is synthesized from AA by COX (or PTGS) enzymes. Then, prostaglandin E synthases (PTGES) are involved in further modification of $\mathrm{PGH}_{2}$ to pro-inflammatory $\mathrm{PGE}_{2}$. PGES include
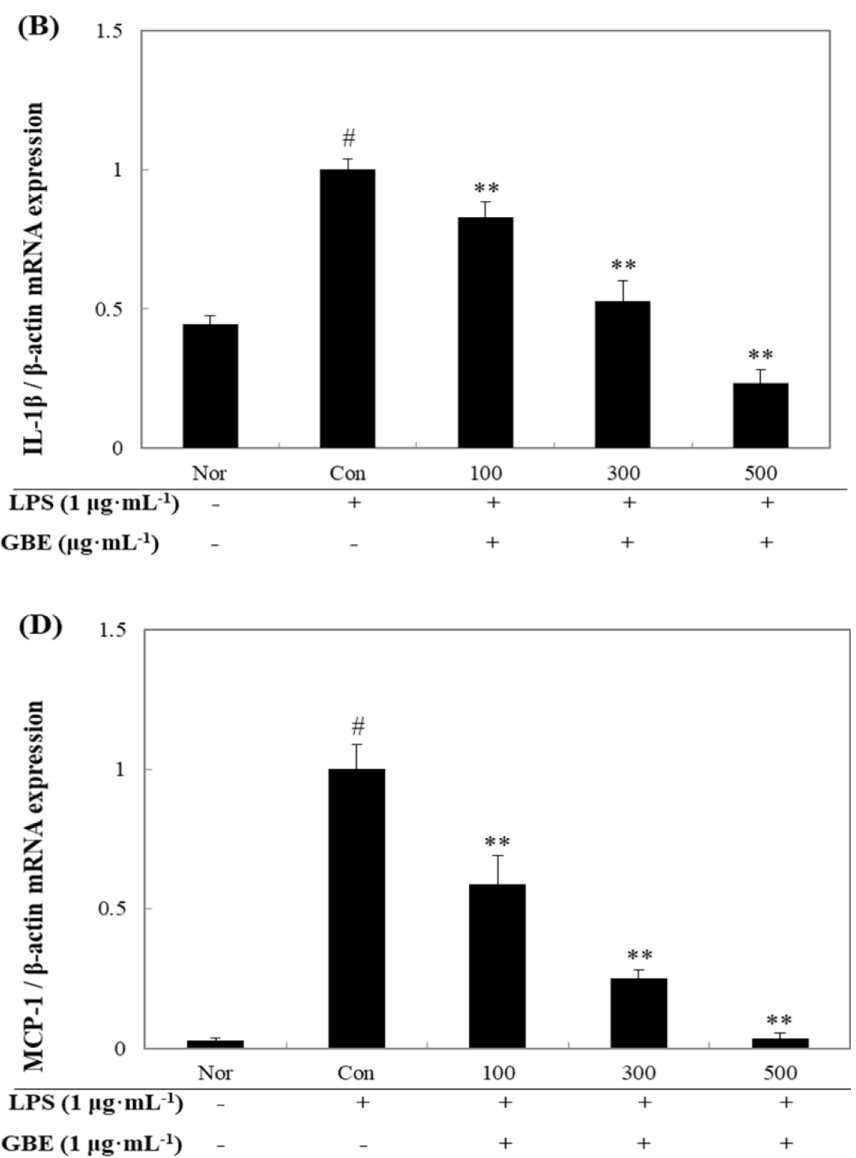

Fig. 5 Effect of GBE on pro-inflammatory marker gene expression in Raw 264.7 macrophages stimulated with LPS. Raw 264.7 macrophages were treated with LPS $(1 \mu \mathrm{g} / \mathrm{mL})$ in the presence of different concentrations of GBE $(100-500 \mu \mathrm{g} / \mathrm{mL})$ for $18 \mathrm{~h}$. The mRNA expression of the pro-inflammatory marker genes TNF- $\alpha$ (A), IL-1 $\beta$ (B), IL-6 (C), MCP-1 (D) and PTGES2 (E), were measured by real-time PCR. Relative mRNA expression levels were normalized to $\beta$-actin. Normal (Nor) group measurements were obtained in the absence of LPS. Control (Con) group was treated with only LPS. The values are mean \pm SD of three independent experiments. ${ }^{*} p<0.05$ compared with normal group, ${ }^{*} p<0.05,{ }^{* *} p<0.01$ compared with control group

cytosolic PTGES (cPTGES), microsomal PTGES1 (mPGES1), and mPTGES2 [24]. Resulting $\mathrm{PGE}_{2}$ increases blood flow, pain, redness, and edema of tissues [13]. MCP-1 functions as a chemokine that controls the movement of immune-related cells, such as monocytes, to the infection site in the early stage of the inflammatory response [25]. Monocytes recruited by MCP-1 differentiate into macrophages and secrete inflammatory cytokines (TNF- $\alpha$, IL-6, IFNs) to intensify the inflammatory response. Therefore, MCP-1 plays an important role in the early inflammatory response, which is involved in the pathogenesis of several diseases 
characterized by mononuclear cell infiltration, such as psoriasis, rheumatoid arthritis, and atherosclerosis [26].

This evidence suggests that GBE, a physiologically active phenolic substance contained in Green ball apples, inhibits the expression and/or activation of iNOS, COX-2, and NF- $\mathrm{kB}$, thereby suppressing the expression of various pro-inflammatory biomarker genes. Our results suggest that GBE is a valuable health-related functional material that can be used for treating inflammation-related disorders like skin aging.

Inflammation-inhibitory effects were measured utilizing ELISA, western blotting and real-time PCR for inflammation-related factors utilizing GBE. As a result, NO expression was suppressed by GBE. iNOS, COX-2, and NF- $\mathrm{B}$ p 65 protein expression levels were inhibited in a concentration-dependent manner. mRNA expressions of pro-inflammatory factors TNF- $\alpha$, IL-1 $\beta$, IL-6, MCP-1, and PTGES2 were significantly suppressed. Besides, monocytes collected by MCP-1 are differentiated into macrophages and stimulated by inflammatory cytokine (TNF- $\alpha$, IL-1 $\beta$, IL-6) and COX that are involved in the inflammatory response, thereby inhibiting PTGES2 involved in $\mathrm{PGE}_{2}$ expression.

\section{References}

1. Lee EH, Kim YJ, Kwon SI, Kim JH, Kang IK, Kim BO, Cho YJ (2018) Functional properties of newly bred Green ball apple (Malus pumila Mill.). Kor J Food Preserv 25: 837-845

2. Yun HJ, Lim SY, Hur JM, Jeong JW, Yang SH, Kim DH (2007) Changes of functional compounds in, and texture characteristics of, apples, during post-irradiation storage at different temperatures. Kor J Food Preserv 14: 239-246

3. Kwon OJ (2016) Antioxidant and tyrosinase inhibitory activities of immature fruits of Malus pumila cv. Fuji. Kor J Food Preserv 23: 585590

4. Yoon Y, Bae S, An S, Choe YB, Ahn KJ, An IS (2013) Effects of ultraviolet radiation on the skin and skin cell signaling pathways. Asia $\mathrm{J}$ Beauty Cosmet 11: 417-426

5. Lee HY, Kim GJ, Kim YS, Lee SN, Lee SO (2007) Skin science. Koonja Publisher, Paju, Korea. pp 20-24

6. Kim J, Lee CW, Kim EK, Lee SJ, Park NH, Kim HS, Kim HK, Char K, Jang YP, Kim JW (2011) Inhibition effect of Gynura procumbens extract on UV-B-induced matrix-metalloproteinase expression in human dermal fibroblasts. J Ethnopharm 137: 427-433

7. Lundberg IE (2000) The role of cytokines, chemokines and adhesion molecules in the pathogenesis of idiopathic inflammatory myopathies. Curr Rheumat Rep 2(3): 216-224

8. EI-Mahmoudy A, Matsuyama H, Brogan MA, Shimizu Y, EI-Sayed MG, Minamoto N, Takewaki T (2002) Thymoquinone suppress expression of inducible nitric oxide synthesis in rat macrophage. Inter Immunopharm 2(11): 1603-1611

9. Gilroy DW, Lawrence T, Perretti M, Rossi AG (2004) Inflammatory resolution: new opportunities for drug discovery. Nat Rev Drug Discov 3: $401-416$

10. Kim SN, Lee CM, Lee SH, Kim YC (2013) Inhibitory efficacy of watersoluble extracts from green, white and black teas on MMP-2 activity and MMP-1 gene expression in human dermal fibroblasts. J Invest Cosmet 9: $21-26$

11. Claude S, Manabu K, Laura M, Lester P (1999) Antioxidants modulate acute solar ultraviolet radiation-induced NF-kappa-B activation in a human keratinocyte cell line. Free Radic Biol Med 26: 174-183

12. Gloire G, Legrand-Poels S, Piette J (2006) NF- $\kappa$ B activation by reactive oxygen species: fifteen years later. Biochem Pharmacol 72: 1493-1505

13. Lee KH, Rhee KH (2015) Screening of anti-inflammatory herbs having the activation of MAPK family proteins. Kor J Food Nutr 28(3): 343 350

14. Carmichael J, DeGraff WG, Gazdar AF, Minna JD, Mitchell JB (1987) Evaluation of a tetrazolium based semiautomated colorimetric assay: assessment of chemosensitivity testing. Cancer Research 47: 936-942

15. Zhang D, Zhang H, Lao YZ, Wu R, Xu JW, Murad F, Bian K, Xu HX (2015) Anti-inflammatory effect of 1,3,5,7-tetrahydroxy-8-isoprenylxanthone isolated from twigs of Garcinia esculenta on stimulated macrophage. Mediators Inflamm 2015: 1-11

16. Aderem A, Ulevitch RJ (2000) Toll-like receptors in the induction of the innate immune response. Nature 406: 782-787

17. Dilshara MG, Lee KT, Kim HJ, Lee HJ, Choi YH, Lee CM, Kim LK, Kim GY (2014) Anti-inflammatory mechanism of alphaviniferin regulates lipopolysaccharide-induced release of proinflammatory mediators in BV2 microglial cells. Cell Immunol 290: 21-29

18. Ivashkiv LB (2011) Inflammatory signaling in macrophages: transitions from acute to tolerant and alternative activation states. Eur J Immunol 41: 2477-2481

19. Ha U, Lim JH, Jono H, Koga T, Srivastava A, Malley R, Pages G, Pouyssegur J, Li JD (2007) A novel role for IkappaB kinase (IKK) alpha and IKKbeta in ERK-dependent up-regulation of MUC5AC mucin transcription by Streptococcus pneumoniae. J Immunol 178: 1736-1747

20. Kim SJ, Um JY, Lee JY (2011) Anti-inflammatory activity of hyperoside through the suppression of nuclear factor-kappaB activation in mouse peritoneal macrophages. Am J Chin Med 39: 171-181

21. Li Q, Verma IM (2002) NF-kappaB regulation in the immune system. Nat Rev Immunol 2: 725-734

22. Takeuchi O, Hoshino K, Kawai T, Sanjo H, Takada H, Ogawa T, Takeda K, Akira S (1999) Differential roles of TLR2 and TLR4 in recognition of gram-negative and gram-positive bacterial cell wall components. Immunity 11: 443-451

23. Daghigh F, Fukuto JM, Ash DE (1994) Inhibition of rat liver arginase by an intermediate in NO biosynthesis, NG-hydroxy-L-arginine: implications for the regulation of nitric oxide biosynthesis by arginase. Biochem Biophys Res Commun 202(1): 174-180

24. Schlondorff D, Peter JN, Bruno L, Bernhard B (1997) Chemokines and renal disease. Kidney Int 51: 10-11

25. Wada T, Yokoyama H, Su SB, Mukaida N, Iwano M, Dohi K, Takahashi Y, Sasaki T, Furuichi K, Segawa C, Hisada Y, Ohta S, Takasawa K, Kobayashi KI, Matsushima K (1996) Monitoring urinary levels of monocyte chemotactic and activation factor reflects disease activity of lupus nephritis. Kidney Int 49: 761-767

26. Jin CH, Park YD, Choi DS, Jeong IY (2010) Study on the mechanism of radiation-induced MCP-1 expression in Raw264.7 macrophage cells. J Radiat Ind 4(3): 227-231 